\title{
Kajian Kebijakan Proses Pengambilan Keputusan di Perguruan Tinggi di Era Revolusi Industri
}

\author{
Muhammad Azis ${ }^{1 *}$, Amirullah Abduh ${ }^{2}$ \\ ${ }^{1,2}$ Universitas Negeri Makassar, Indonesia \\ ${ }^{1}$ Email: mazis@unm.ac.id ,2Email: amirullah@unm.ac.id \\ * Corresponding author
}

\begin{abstract}
This article aims to describe the process of decision-making and the effective method of disseminating the decision result. This descriptive research use questionannaires and interviews for data collection. The result of the study shows that the process of decision-making is predominantly done through the formal process of the combination of top-down and bottom up mechanisms. The approach for dissemination of meeting result is done through traditional approach of formal meeting and social media. The implication of this process is that the formal meeting is the best best possible option in the process of decision-making. This mechanism allows every participant to contribute to providing suggestions in creating effective decision-making. This research contributes to the development and the debates on the policy and mechanism of decision-making process.
\end{abstract}

Keywords: Decision Making Process; Mechanism; Socialization; Higher Education

\begin{abstract}
Abstrak. Artikel ini bertujuan untuk mendeskripsikan tentang proses pengambilan dan metode yang efektif untuk diseminasi hasil keputusan. Penelitian ini menggunakan angket dan wawancara yang mendalam terhadap responden yang terlibat dalam penelitian ini. Hasil penelitian menunjukan bahwa proses pengambilan keputusan yang paling diharapkan oleh seluruh subyek penelitian ini ialah gabungan top-down dan bottom up dengan mekanisme pengambilan suara atau keputusan secara formal. Pengambilan keputusan secara formal melibatkan pimpinan maupun bawahan dan disesuaikan dengan output rapat. Mekanisme diseminasi yang dominan ialah diseminasi yang bersifat tradisional yakni melalui rapat dan melalui jejaring sosial. Implikasi dari hasil penelitian ini menunjukan bahwa proses formal dalam pengambilan keputusan melalui rapat umum atau rapat terbatas masih menjadi pilihan proses pengambilan keputusan sehingga model tradisional ini memberi ruang kepada semua elemen yang terlibat untuk berpatisipasi dan memberi saran yang konstruktif untuk pengambilan keputusan yang efektif.
\end{abstract}

Kata kunci: Proses Pengambilan Keputusan; Mekanisme; Sosialisasi; Pendidikan Tinggi

\section{PENDAHULUAN}

Proses pengambilan keputusan dalam sebuah organisasi menjadi salah satu topik penting yang dibahas oleh berbagai peneliti, penulis dan pemerhati pendidikan bidang budaya organisasi. Proses pengambilan keputusan dalam sebuah organisasi mencerminkan budaya dan ciri khas sebuah organisasi. Organisasi yang sehat sangat ditentukan oleh salah satunya proses pengambilan keputusannya, terutama organisasi yang berada di era revolusi industri sekarang ini.

Pengambilan keputusan merupakan suatu kegiatan yang berhubungan dengan proses menentukan suatu pilihan diantara banyaknya tantangan dan pilihan (Lunenburg, 2012). Hal ini bermakna bahwa pengambilan keputusan itu berarti proses pemilihan alternatif yang terbaik dari berbagai pilihan yang tersedia. Lebih lanjut, beberapa peneliti dari negara Brazil, Marchisotti dan Almeida (2018) menjelaskan bahwa proses pengambilan keputusan merupakan puncak dari sebuah proses penting dalam suatu budaya organisasi, karena pengambilan keputusan akan menentukan arah kebijakan organisasi dan program ke depan suatu organisasi. Oleh karena itu, suatu organisasi yang memiliki budaya yang sehat, kuat dan profesional menempatkan 
proses pengambilan keputusan menjadi momentum inti dalam rangkaian kegiatan organisasi.

Konsep tentang mekanisme pengambilan keputusan telah banyak diteliti oleh berbagai peneliti di dunia. Wallach, Allen, dan Smit (2008) mengemukakan bahwa proses pengambilan keputusan dilakukan dengan dua cara: top down dan bottom-up. Metode tersebut juga dipengaruhi oleh moral dan watak orangorang yang tergabung dalam suatu organisasi. Lebih lanjut, peneliti seperti Kim, Sting, dan Loch, (2014) menjelaskan bahwa proses pengambilan keputusan dalam suatu organisasi perlu mengintegrasikan antara keduannya sehingga hasil keputusan yang diambil dapat dipertanggungjawabkan dan diterima banyak kalangan. Penggabungan metode proses pengambilan keputusan tersebut juga didukung oleh peneliti lain yakni peneliti-peneliti yang tergabung dalam kelompok pemerhati proses pengambilan keputusan dalam suatu organisasi (Hornung, Rousseau, Glaser, Angerer, \& Weigl, 2010; Li, Andersen, \& Hallin, 2019). Para peneliti di atas menunjukan bahwa pentingnya proses pengambilan keputusan yang menggabungkan antara top down dan bottom-up proses.

Di sisi lain, peneliti seperti Biesbroek dkk (2015), Callon, Beach, Links, Wasserman, \& Boss, (2018), dan Peschel, Orquin, \& Loose (2019) mengatakan bahwa proses pengambilan yang menjamin keadilan dan keberpihakan kepada semua ialah mekanisme bottom-up. Alasannya ialah banyak keputusan yang diambil oleh pimpinan tidak pernah melibatkan para bawahan sehingga sangat menguntungkan sebagian kecil kelompok dalam suatu organisasi. Demikian halnya, Apostolopoulos dan Liargovas (2018) menambahkan bahwa proses pengambilan keputusan melalui mekanisme bottom-up dapat mengakomodir banyak kepentingan arus kelompok marginal sehingga bisa menjadi pilihan yang tepat dalam setiap pengambilan keputusan.

Peneliti-peneliti lain juga tidak sepenuhnya menyetujui bahwa mekanisme bottom-up merupakan suatu pilihan yang tepat. Turpin dan Marais (2004) mengemukakan bahwa proses pengambilan keputusan yang efektif dan cepat hanya dapat dilakukan secara top-down karena prosesnya tidak terlalu panjang dan mekanismenya sangat sederhana. $\mathrm{Wu}$ (2015) menjelaskan bahwa proses pengambilan keputusan dalam suatu organisasi terutama dengan mekanisme top-down merupakan suatu proses investasi yang menghemat energi bagi semua pihak.

Penelitian tentang budaya organisasi di dunia telah banyak dilakukan. Namun di Indonesia, penelitian tentang budaya organisasi masih perlu dilakukan karena belum banyak penelitian khususnya terkait dengan proses pengambilan keputusan serta strategi yang efektif untuk melakukan diseminasi keputusan terhadap anggota organisasi. Oleh karena itu, artikel ini bertujuan untuk memberikan deskripsi tentang mekanisme pengambilan keputusan di sebuah perguruan tinggi dan strategi desiminasi kegiatan tersebut. Artikel ini memberi kontribusi terhadap budaya organisasi dalam hal pengambilan keputusan dan diharapkan dapat menambah khasanah pengetahuan dan kajian baru baik di tingkat nasional maupun internasional di bidang pengambilan keputusan dalam suatu organisasi.

\section{METODE PENELITIAN Desain penelitian}

Desain penelitian yang digunakan dalam penelitian ini adalah penelitian deskriptif. Sandelowski (2000) menjelaskan bahwa penelitian deskriptif berkaitan dengan apa dan bagaimana fenomena yang diteliti. Penelitian deskriptif ini sangat tepat untuk digunakan untuk menganalisis proses pengambilan keputusan dalam sebuah organisasi terutama dalam konteks perguruan tinggi.

\section{Instrumen penelitian}

Penelitian ini mengungkap secara mendalam tentang proses pengambilan keputusan dengan instrument angket dan wawancara. Angket ini disebarkan melalui email pada salah satu jurusan dan hasil angket tersebut menjadi salah satu bahan untuk wawancara lanjutan. Dalam proses pembuatan angket dilakukan beberapa hal: 1) untuk memastikan bahwa angket itu andal, maka seluruh isi angket dilakukan pre-test: 2) pre-test dilakukan kepada dosen untuk memberi masukan dan mengisi agar terhindar dari kesalahan dan bias. Demikian juga, pertanyaan wawancara dilakukan validasi oleh dosen sehingga daftar pertanyaan wawancara tersebut valid dan andal. Proses ini dinamakan proses validasi instrumen (Gall, Gall, \& Borg, 2007).

\section{Responden penelitian}

Responden dalam penelitian ini ialah 14 dosen yang memenuhi beberapa kriteria yakni: 1) memiliki tugas tambahan minimal 
ketua prodi; 2) memiliki pengalaman mengajar minimal 10 tahun. Kriteria ini digunakan untuk mendapat informasi yang mendalam dan tepat serta memilih responden yang pengalaman dalam proses pengambilan keputusan.

\section{Langkah-langkah pengumpulan data}

Pengumpulan data melalui angket mengikuti beberapa langkah sebagai berikut: 1) mengidentifikasi responden yang memenuhi kriteria tersebut di atas; 2) mengirimkan angket melalui surat elektronik kepada dosen yang menjadi calon responden; 3) dalam angket, terdapat kesediaan untuk diwawancara; 4) melakukan wawancara seluruh dosen (14 responden) sesuai kesediaannya.

\section{Metode analisis data}

Data angket dianalisis melalui Ms.

Excel untuk melihat persentase dan gambaran tentang proses pengambilan keputusan. Sedangkan data wawancara, analisis data yang dilakukan pada penelitian menggunakan pendekatan tematik. Menurut Braun dan Clarke (2006), pendekatan tematik ialah pendekatan yang digunakan untuk melihat data secara keseluruhan, memberi kode-kode tertentu terhadap data yang dianggap penting, memberi tema terhadap kode-kode tersebut, mengumpulkan sub tema untuk dijadikan bahan dalam menentukan kategori umum terkait data penelitia, dan akhirnya semua tema-tema tersebut dimasukan ke dalam tulisan sebagai bagian dari hasil penelitian.

\section{HASIL DAN PEMBAHASAN}

Proses pengambilan keputusan di perguruan tinggi

Proses pengambilan keputusan menjadi tema yang sangat menarik untuk dibahas karena berdasarkan hasil angket dan wawancara bahwa terdapat tiga mekanisme proses pengambilan keputusan yakni: top-down, bottom up dan gabungan dari top-down dan bottom-up. Grafik 1: Mekanisme proses pengabilan keputusan

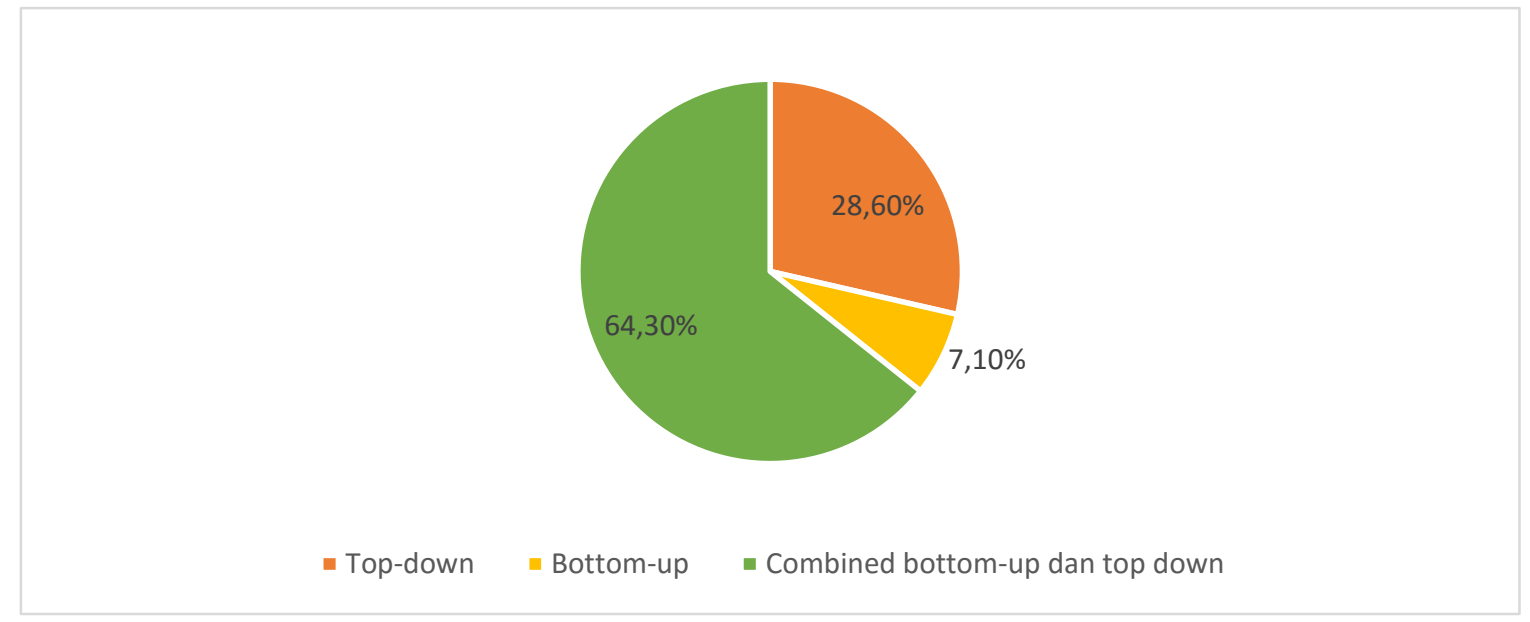

Mekanisme yang paling dominan yang diharapkan oleh para dosen ialah kombinasi antara top down dan bottom up proses. Hal ini berarti bahwa pihak civitas akademika terutama dosen sangat mengharapkan keterlibatan pihak pimpinan dan bawahan dalam proses pengambilan keputusan terutama yang menyangkut hajat dan kepentingan bersama. Dari statistik diatas juga menunjukan bahwa gabungan ini harus menjadi pilihan utama dan panduan bagi pimpinan dalam suatu organisasi dalam proses pengambilan keputusan.

Mekanisme top-down ialah proses pengambilan keputusan yang hanya melibatkan pejabat tinggi dan diinisiasi oleh mereka. Proses ini sangat eksklusif dan dihadiri oleh anggota yang terbatas. Proses ini juga hanya dilakukan untuk mengambil keputusan-keputusan yang mendesak sehingga dapat dicapai kesepakatan dalam waktu singkat dan dilaksanakan dalam waktu yang mendesak juga. Sedangkan, proses keputusan yang berasal dari arus bawah bottomup sedikit diminati oleh para dosen karena proses ini sangat memerlukan energi yang banyak, mekanisme yang cukup panjang dan proses yang lebih lama.

Berdasarkan respon partisipan dalam penelitian ini menunjukan bahwa proses pengambilan keputusan ialah penggabungan bottom-up dan top down. Beberapa alasan yang dikemukan oleh responden terkait pentingnya gabungan antara bottom-up dan top down proses (Tabel 1) antara lain: 
Tabel 1: Pentingnya proses pengambilan keputusan

\begin{tabular}{ll}
\hline Dosen & Pandangannya \\
\hline A & $\begin{array}{l}\text { Ada masalah tertentu pimpinan mengambil keputusan sendiri dan memberikan instruksi } \\
\text { kepada bawahannya, akan tetapi pada masalah tertentu, pimpinan menerima masukan dari } \\
\text { bawahannya. }\end{array}$ \\
B & $\begin{array}{l}\text { Dikembalikan ke kondisi yang terjadi, jika itu merupakan aturan dari pimpinan maka akan } \\
\text { disosialisasikan ke unit-unit di bawahnya. Tetapi jika terkait dengan masalah akademik } \\
\text { mahasiswa maka akan diselesaikan pada tingkat prodi dengan pembimbing akademik } \\
\text { dilanjutkan ke pihak fakultas. }\end{array}$ \\
Dalam penentuan rencana strategis dan rencana operasional fakultas serta program studi, \\
visi dan misinya bersumber dari visi dan misi universitas (top down), kemudian program \\
kerjanya berdasarkan kebutuhan program studi serta fakultas (bottom-up) \\
Keputusan pengajuan kuota penerimaan maba oleh kaprodi melalui rapat fakultas tidak \\
sesuai dengan kenyataan setelah melalui pusat atau pucuk pimpinan \\
K & $\begin{array}{l}\text { Keputusan tentang pelaksanaan PMB (penerimaan mahasiswa baru) di fakultas masing } \\
\text { masing sudah ditentukan jadwal dan waktu pelaksanaanya secara serentak, namun untuk } \\
\text { teknis kegiatan diserahkan kepada panitia pelaksana kegiatan PMB }\end{array}$ \\
\hline
\end{tabular}

Contoh tindak lanjut keputusan yang bersifat penggabungan pengambilan keputusan yang bersifat bottom-up dan top down ialah terkait penerimaan mahasiswa baru, kebijakan penentuan program kerja prioritas sebuah institusi, penentuan UKT dan aktivitas lembaga kemahasiswaan. Dosen yang terlibat dalam penelitian menjelaskan bahwa kombinasi proses pengambilan keputusan sangat penting karena tidak semua keputusan harus bersifat top down dan sebaliknya tidak semua keputusan harus bersifat bottom-up. Oleh karena itu, kelihaian dan kepemimpinan yang baik, sehat dan profesional akan mampu melihat dan memilih mekanisme pengambilan keputusan yang tepat yang sesuai dengan situasi, keperluan dan kepentingan organisasi saat itu.

Proses pengambilan keputusan dalam suatu organisasi yang menggabungkan dua mekanisme top-down dan bottom up memiliki implikasi pada suatu organisasi. Implikasinya sama seperti yang di kemukakan oleh Wallach, Allen, dan Smit (2008) bahwa pengambilan keputusan top-down selalu mempertimbangkan mekanisme standar dan etika organisasi, sedangkan mekanisme bottom-up selalu mempertimbangkan aspek-aspek yang dapat melahirkan standar atau konsep yang menjadi landasan organisasi. Lebih lanjut lagi, Kim, Sting, dan Loch (2014) menjelaskan bahwa penggabungan proses pengambilan tentang suatu hal dalam sebuah organisasi biasa dilakukan, karena mekanisme pengambilan keputusan top-down cenderung memperhatikan macro level. Macro level yang dimaksud ialah mekanisme pengambilan keputusan yang memperhatikan suara yang lebih banyak dan kepentingan yang lebih luas. Sedangkan proses pengambilan keputusan bottom up cenderung memperhatikan micro level, yakni kepentingan sekelompok orang dalam suatu organisasi. Kim, Sting, dan Loch (2014) lebih spesifik lagi menjelaskan bahwa mekanisme pengambilan keputusan top-down bersifat sentralistik dan mekanisme pengambilan keputusan bottom-up bersifat disentralisasi. Sentralistik yang dimaksud ialah proses pengambilan keputusan yang dilakukan pimpinan utama atau level dekan dan wakil dekan pada tingkat fakultas. Sedangkan mekanisme keputusan yang bersifat disentralisasi yakni diibaratkan keputusan yang dibuat pada tingkat program studi, yang kemudian disahkan oleh anggota senat dan pimpinan fakultas.

Implikasi lainnya ialah hasil pengambilan keputusan bottom-up memerlukan proses yang lebih panjang dan kompleks untuk dilaksanakan karena perlu persetujuan pimpinan organisasi. Tapi kelebihan dari keputusan yang diambil melalui mekanisme bottom-up ialah memberikan keleluasaan kepada bawahan untuk memodifikasi cara untuk melaksanakan hasil keputusan (Hornung, Rousseau, Glaser, Angerer, \& Weigl, 2010). Sedangkan hasil keputusan yang diambil dari mekanisme topdown tidak memiliki tantangan yang rumit untuk dilaksanakan, namun memiliki tantangan dalam hal cara untuk mendorong bawahan agar memiliki motivasi dan semangat yang optimal dalam menjalankan hasil keputusan yang dibuat melalui mekanisme top-down (Hornung, Rousseau, Glaser, Angerer, \& Weigl, 2010). 
Proses pengambilan keputusan dalam suatu organisasi sangat dipengaruhi oleh kemampuan pemimpin. Pandangan dosen terkait pentingnya kepempinan yang baik dalam proses pengambilan keputusan (Tabel 2) antara lain:

Tabel 2: Pentingnya kepemimpinan dalam proses pengambilan keputusan

\begin{tabular}{ll}
\hline Dosen & $\begin{array}{l}\text { Pandangannya terkait pentingnya kemampuan pemimpin dalam proses pengambilan } \\
\text { keputusan }\end{array}$ \\
\hline $\mathrm{F}$ & $\begin{array}{l}\text { Dalam melaksanakan pekerjaan terdapat banyak pilihan yang memililiki resiko dan } \\
\text { dampak masing-masing oleh karena itu kemampuan mengambil keputusan yang kira-kira } \\
\text { berdampak baik baik orgnisasi dengan resiko yang kecil. }\end{array}$ \\
$\mathrm{G}$ & $\begin{array}{l}\text { Untuk mendapatkan hasil yang maksimal dalam pekerjaan, maka kemampuan mengambil } \\
\text { keputusan juga sangat diperlukan. }\end{array}$ \\
$\mathrm{H}$ & $\begin{array}{l}\text { Kemampuan menentukan keputusan pada berbagai alternatif pilihan ciri kepemimpinan } \\
\text { organisasi yang solid }\end{array}$ \\
I & $\begin{array}{l}\text { Karena kemampuan mengambil keputusan akan menjadi arah mencapaian tujuan dan } \\
\text { kemampuan dapat mempengaruhi keputusan yang diambil, keputusan yang cepat dan tepat } \\
\text { dapat menghasilkan hasil kerja yang berkualitas. }\end{array}$ \\
$\mathrm{J}$ & $\begin{array}{l}\text { Tidak dievaluasi secara berkelanjutan akan mempengaruhi proses keputusan dan akan } \\
\text { sangat menentukan sebuah momentum kesuksesan individu dan organisasi }\end{array}$ \\
$\mathrm{K}$ & $\begin{array}{l}\text { Pengambilan keputusan yang baik membutuhkan pengetahuan dan keterampilan yang } \\
\text { mumpuni akan berdampak kepada bawahan dan pengembangan diri dan aktualisasi diri }\end{array}$ \\
$\mathrm{L}$ & $\begin{array}{l}\text { Sebab setiap keputusan yang diambil pasti akan ada konsekuaensinya, tinggal bagaimana } \\
\text { semua itu dapat dipertanggungjawabkan dan dilaksanakan dengan sebaik mungkin untuk }\end{array}$ \\
hasil yang optimal & $\begin{array}{l}\text { Asalkan tugas selesai. Keputusan yang tepat berarti pelaksanaan pekerjaan sudah selesai } \\
50 \%\end{array}$ \\
&
\end{tabular}

Dari tabel tersebut di atas, pentingnya kepemimpinan yang solid, baik, bertanggungjawab, berani menanggung resiko, mampu mengambil keputusan yang cepat dan tepat, memiliki cara mengevaluasi pekerjaan secara berkelanjutan, dan memiliki pengetahuan dan keterampilan tentang cara untuk mengambil keputusan. Kepemimpinan yang solid dan baik yang dimaksud di atas ialah kepemimpinan yang memiliki keinginan untuk mendengarkan pandangan dari bawahan dan pimpinan unit terendah (Li, Andersen, \& Hallin, 2019) dalam sebuah fakultas misalnya ketua prodi atau kepala laboraotrium. Sedangkan kepemimpinan yang bertanggung jawab ialah kepemimpinan yang mau bertanggung jawab atas segala keputusan yang telah ditetapkan dan mencarikan solusi yang terbaik atas keputusan salah yang telah disepakati (Li, Andersen, \& Hallin, 2019). Kepemimpinan yang bertanggung jawab juga berimplikasi pada kesediaan dan keterbukaan untuk menerima segala resiko negatif dan bias dari keputusan yang telah dibuat tanpa menyalahkan bawahannya.

Kepemimpinan yang memiliki pengetahuan dan keterampilan dalam proses pengambilan keputusan akan berdampak pada kekuatan untuk menggerakkan bawahannya. Dengan pengetahuannya, seorang pemimpin misalnya dekan, akan mampu mempengaruhi orang lain atau seluruh elemen yang ada dalam fakultas tersebut karena pengetahuan dan keterampilannya dalam mengambil keputusan yang baik. Kemampuan mempengaruhi orang lain tersebut merupakan suatu ciri kekuatan individu pemimpin. Kekuatan individu tersebut akan sangat mempengaruhi hasil suatu pekerjaan (Lunenburg, 2012). Pemimpin yang memiliki pengetahuan dan keterampilan dalam proses pengambilan keputusan dapat memahami kondisi yang terjadi dan mampu memprediksi kondisi yang akan terjadi, sehingga hasil keputusan yang dibuat memiliki visi dan konsekuensi jangka pendek dan jangka panjang.

Metode efektif untuk sosialisasi hasil keputusan

Hasil penelitian menunjukan bahwa metode yang efektif dan desiminasi hasil keputusan rapat ialah melalui rapat, jejaring sosial, komunikasi lisan secara individu dan email. 


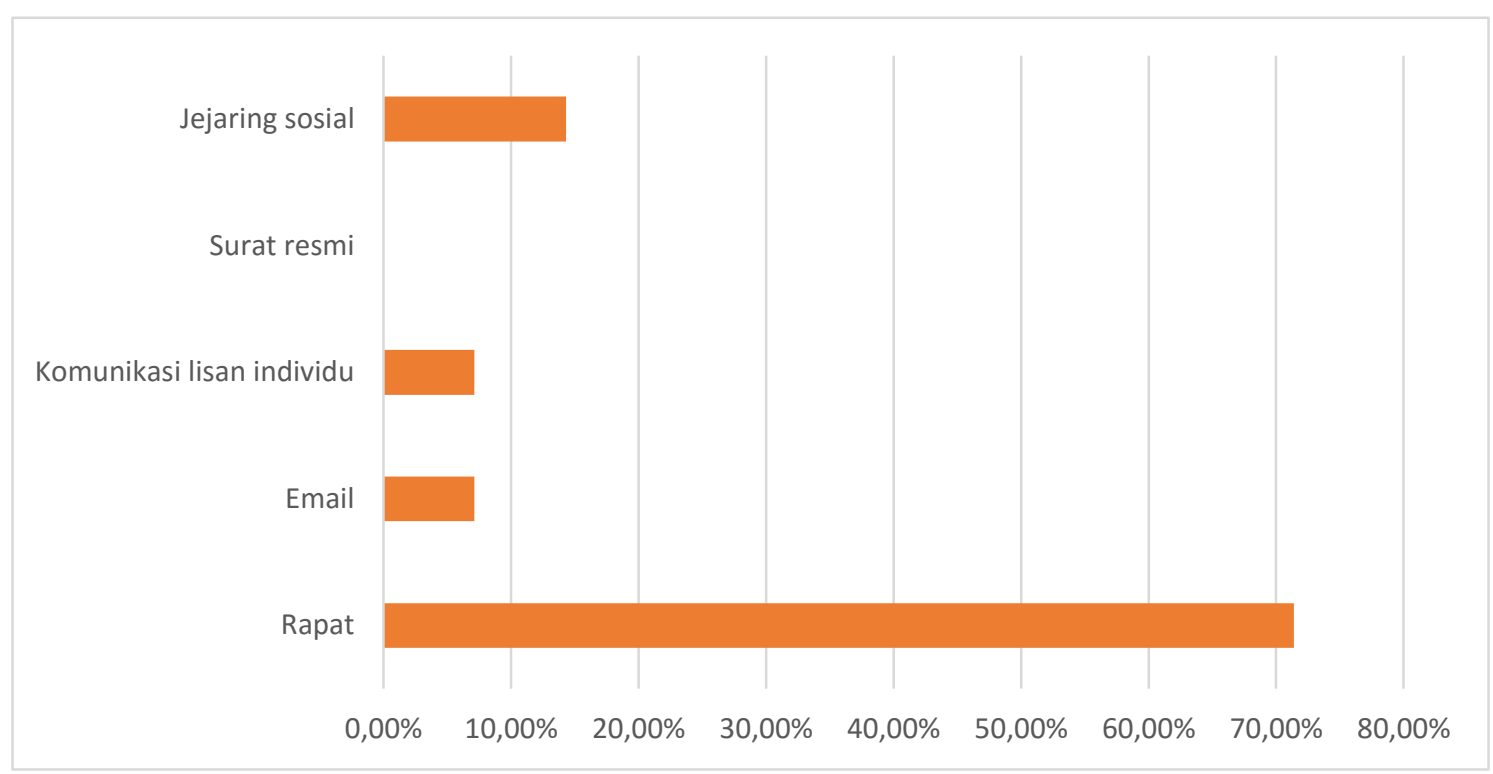

Grafik 2: Mekanisme desiminasi hasil keputusan

Berdasarkan hasil angket menunjukan bahwa mekanisme yang paling diminati oleh responden dalam sosialisasi hasil keputusan ialah mekanisme rapat. Semua hasil keputusan harus didesiminasi lebih dahulu melalui rapat kemudian disosialisasikan dalam bentuk lain. Grafik di atas menunjukan bahwa menghadirkan semua elemen dalam suatu musyawarah atau rapat masih menjadi cara yang efektif untuk desiminasi hasil keputusan bersama karena dengan melalui rapat maka semua elemen yang terlibat dapat memperhatikan dan menyimak hasil keputusan tersebut. Hal tersebut dapat mengurangi distorsi, bias, dan interpretasi lain terhadap hasil keputusan. Hal yang menarik lainnya ialah tidak satupun dosen yang memilih surat resmi sebagai bentuk sosialisasi hasil keputusan. Hal ini bisa saja diartikan bahwa surat resmi terlihat lamban, dan kurang praktis untuk digunakan dalam sosialisasi hasil keputusan. Namun demikian, untuk pengarsipan dan dokumentasi organisasi, surat resmi bisa menjadi salah satu pilihan yang tetap tersedia dalam suatu organisasi.

Sosialisasi hasil keputusan melalui rapat formal memberi beberapa kelebihan antara lain: a) peserta rapat dapat secara demokratis mempertanyakan hasil keputusan rapat jika terdapat kejanggalan dan ketidakjelasan; b) peserta rapat dapat secara langsung memberikan tanggapan atau solusi terhadap isu yang diangkat; c) peserta rapat dapat memilih pilihan yang terbaik di antara pilihan yang tersedia; dan d) peserta rapat dapat memberikan hasil analisa dan review terhadap pilihan yang telah diambil (Turpin dan Marais, 2004). Di samping itu, mekanisme diseminasi hasil keputusan melalui rapat formal memiliki sifat birokratis, hirarki dan paternaslitik

Sedangkan keuntungan lain dari proses diseminasi hasil keputusan melalui rapat ialah mencegah bias informasi karena semua pihak terkait telah hadir bersama untuk mendengarkan hasil keputusan. Hal ini memberikan keuntungan terkait efisiensi waktu, tenaga dan mengurangi mekanisme birokrasi dalam suatu organisasi. Mekanisme tersebut mencerminkan gaya kepemimpinan dalam organisasi, ciri khas kepemimpinan dan visi futuristik kepemimpinan dalam organisasi (Elayyan \& Shra, 2015). Proses diseminasi hasil keputusan tersebut juga mencerminkan budaya suatu organisasi.

Beberapa alasan dosen tentang pentingnya sosialisasi hasil keputusan melalui rapat formal sebagaimana di bawah ini (Tabel $3)$ : 
Tabel 3: Pentingnya sosialisasi hasil keputusan melalui rapat

\begin{tabular}{|c|c|}
\hline Dosen & Pandangannya \\
\hline $\mathrm{A}$ & $\begin{array}{l}\text { Dengan pertemuan pimpinan dapat menyerap aspirasi dan masukan serta mendengarkan } \\
\text { masalah ril yang dihadapi bawahannya sebagai dasar pimpinan dalam membuat keputusan }\end{array}$ \\
\hline B & $\begin{array}{l}\text { Melalui pertemuan baik disengaja maupun tidak dilakukan dengan pimpinan dan teman } \\
\text { sejawat lainnya }\end{array}$ \\
\hline $\mathrm{C}$ & $\begin{array}{l}\text { Pola komunikasi cenderung fleksibel dan cair, kadang pertemuan resmi, bahkan di tempat } \\
\text { olahraga. }\end{array}$ \\
\hline $\mathrm{D}$ & $\begin{array}{l}\text { Pertemuan dilakukan pada awal, tengah, dan akhir semester sehingga maksud dan tujuan } \\
\text { komunikasi jelas dan dapat dipahami. }\end{array}$ \\
\hline $\mathrm{F}$ & Penyampaian ide dilakukan dalam rapat \\
\hline G & $\begin{array}{l}\text { Pertemuan merupakan bentuk komunikasi yang humanis untuk membangun komitmen } \\
\text { dalam organisasi. }\end{array}$ \\
\hline $\mathrm{H}$ & $\begin{array}{l}\text { Karena setiap penyelesaian masalah dibutuhkan musyawarah dan mufakat, dan rapat untuk } \\
\text { menyamakan persepsi }\end{array}$ \\
\hline I & $\begin{array}{l}\text { Sebab hasil komunikasi yang dilakukan untuk melahirkan suatu keputusan yang dapat } \\
\text { dilaksanakan oleh semua pihak dalam organisasi, sehingga perlu diputuskan dalam suatu } \\
\text { forum }\end{array}$ \\
\hline
\end{tabular}

Sosialisasi hasil keputusan melalui rapat formal memiliki keuntungan bagi suatu organisasi antara lain memberi peluang kepada pemimpin untuk mendengar aspirasi dari bawahan, menjalin kerjasama, membangun komunikasi yang lebih fleksibel dan humanis, dan memaksimalkan musyawarah dan mufakat. Hal ini sejalan dengan pernyataan Meagher dan Wait (2008) bahwa pentingnya mekanisme sosialisasi hasil keputusan melalui rapat ialah memberikan peluang transformasi informasi secara lebih cepat dan tepat kepada bawahan atau peserta rapat yang hadir. Keuntungan lain sosialisasi keputusan melalui rapat formal ialah memberi peluang kepada pemimpin untuk memaksimalkan mekanisme standar dan etika yang berlaku untuk menyampaikan hasil keputusan, membangun komuninikasi yang fleksibel dan sederhana, dan mendengarkan aspirasi dari bawahan pada saat yang bersamaan (Marchisotti \& Almeida, 2018).

Sesuai hasil temuan tersebut di atas, maka interpretasi mekanisme proses pengambilan keputusan dan sosialisasinya dapat tergambar dalam grafik di bawah ini:

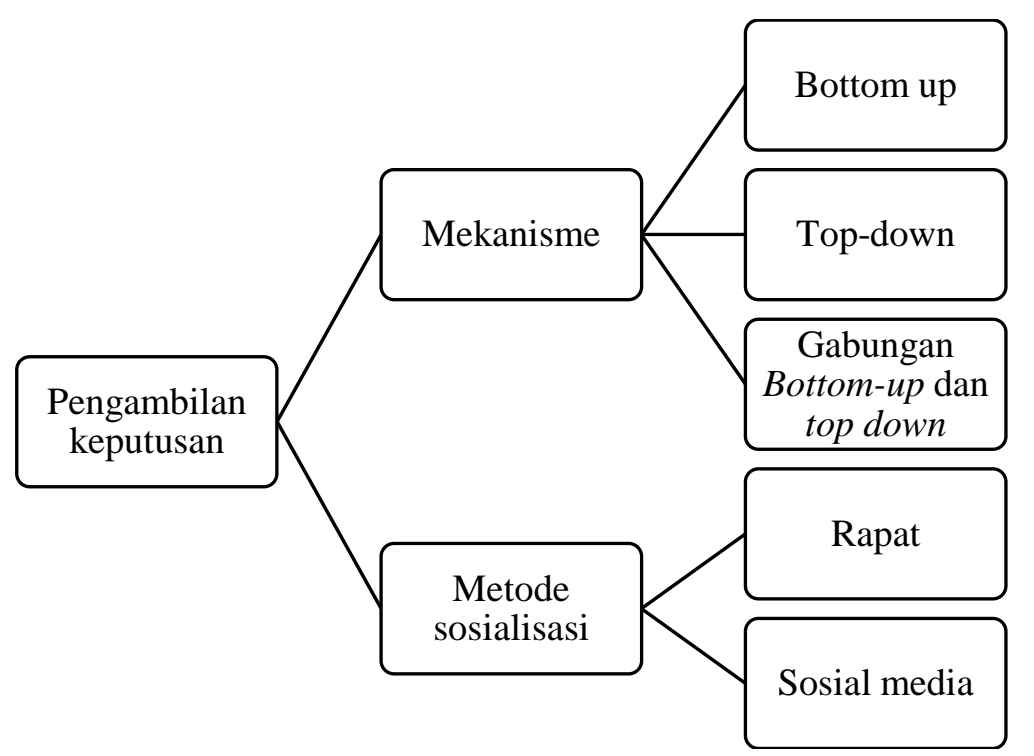

Grafik 3: Pengambilan keputusan: mekanisme dan metode sosialisasinya

Dari bagan tersebut di atas terlihat bahwa mekanisme pengambilan keputusan disesuaikan dengan kebutuhan dan keperluan suatu organisasi. Jika keputusan yang mengharuskan hanya elemen pimpinan saja, maka proses pengambilan keputusan dilakukan 
secara top-down, yakni diinisiasi oleh pimpinan dan kemudian diteruskan dan disosialisasikan kepada bawahan. Proses pengambilan keputusan menjadi pilar yang sangat penting untuk keberlanjutan perjalanan organisasi untuk masa yang akan datang (Obi \& Agwu, 2017). Implikasinya ialah mekanisme pengambilan keputusan yang efektif dalam konteks Indonesia ialah melalui mekanisme gabungan top-down dan bottom-up. Mekanisme tersebut memiliki implikasi kepada organisasi dalam dunia pendidikan yakni universitas, institut, sekolah tinggi, politeknik dan akademi komunitas.

Implikasinya ialah:

a. Pemimpin suatu unit perlu memiliki pengetahuan dan keterampilan dalam mengambil keputusan sehingga keputusan yang diambil dapat memecahkan masalah yang dihadapi organisasinya.

b. Pemimpin dalam suatu organisasi perlu memiliki tanggung jawab dan keberanian untuk mengambil resiko atas segala keputusan yang diambil sehingga jika ada efek negatif dari keputusan, maka pemimpin tidak menyalahi bawahannya.

c. Pemimpin yang baik dan visioner selalu memperhatikan, mendengarkan dan memahami aspirasi bawahannya sehingga keputusan yang diambil sesuai dengan tuntutan kebutuhan bersama.

d. Pemimpin perlu mensosialisasikan hasil keputusan bersama melalui mekanisme rapat formal dan jejaring sosial, disesuaikan dengan kondisi dan aturan yang berlaku dalam organisasi tersebut.

\section{KESIMPULAN}

Berdasarkan temuan di atas, maka beberapa kesimpulan penting dalam penelitian ini ialah:

- Mekanisme pengambilan keputusan terbaik yang paling diharapkan oleh dosen ialah gabungan antara top-down dan bottom-up. Mekanisme ini berarti bahwa proses pengambilan suatu keputusan tidak hanya mendengarkan suara pimpinan saja, melainkan juga mendengarkan suara bawahan sehingga hasil keputusan yang diambil merupakan representase antara kaum elit dan kaum marginal serta merupakan aspirasi bersama dalam suatu organisasi.

- Metode sosialisasi hasil keputusan yang paling efektif menurut responden dalam penelitian ini ialah mekanisme rapat. Melalui rapat yang melibatkan pimpinan atau bawahan saja ataupun melibatkan kedua-keduanya akan sangat efektif untuk mendesiminasikan hasil keputusan rapat. Karena melalui rapat, hasil keputusan yang disampaikan bisa didengarkan langsung sehingga akan mengurangi interpretasi yang berbeda dari setiap orang atas hasil keputusan rapat yang telah diputuskan.

Acknowledgement

Artikel ini merupakan salah satu hasil penelitian PNBP Pasca Sarjana Universitas Negeri Makassar tahun 2019 dengan Nomor kontrak: 838/UN36.9/PL/2019.

Conflict of Interest

Tidak ada konflik kepentingan dalam penelitian ini.

\section{REFERENSI}

Apostolopoulos, N., \& Liargovas, P. (2018). Unlock local forces and improve legitimacy: A decision making scheme in the European Union towards environmental change. European Policy Analysis, 4(1), 146-165.

Biesbroek, R., Dupuis, J., Jordan, A., Wellstead, A., Howlett, M., Cairney, P., ... Davidson, D. (2015). Opening up the black box of adaptation decision-making. Nature Climate Change, 5(6), 493-514.

Braun, V., \& Clarke, V. (2006). Using thematic analysis in psychology. Qualitative Research in Psychology, 3(2), 77-101.

Callon, W., Beach, M. C., Links, A. R., Wasserman, C., \& Boss, E. F. (2018). An expanded framework to define and measure shared decision-making in dialogue: A 'top-down' and 'bottomup'approach. Patient Education and Counseling, 101(8), 1368-1377.

Elayyan, A., \& Shra, M. Al. (2015). The Impact of Decision Making Styles on Organizational Learning: An Empirical Study on the Public Manufacturing Companies in Jordan. International Journal of Business and Social Science, 6(4), 55-62.

Gall, M., Gall, J., \& Borg, W. (2007). Educational research: an introduction. Boston: Pearson/ Allyn \& Bacon.

Hornung, S., Rousseau, D. M., Glaser, J., Angerer, P., \& Weigl, M. (2010). Beyond top-down and bottom-up work redesign: Customizing job content through 
idiosyncratic deals. Journal of Organizational Behavior, 31(2-3), 187215.

Kim, Y. H., Sting, F. J., \& Loch, C. H. (2014). Top-down, bottom-up, or both? Toward an integrative perspective on operations strategy formation. Journal of Operations Management, 32(7-8), 462-474.

Li, X., Andersen, T. J., \& Hallin, C. A. (2019). A Zhong-Yong perspective on balancing the top-down and bottom-up processes in strategy-making. Cross Cultural \& Strategic Management.

Lunenburg, F. C. (2012). Decision Making in Organizations. International Journal of Management, Business, and Adminstration, 15(1), 1-9.

Marchisotti, G. G., \& Almeida, R. L. De. (2018). Decision-making at the Firt Managment Level: The Interference of the Organizational Culture. Revista de Administração Mackenzie, 20(3), 1-26. https://doi.org/10.1590/16786971/eRAMR180106

Meagher, K., \& Wait, A. (2008). Decision Making Within Organizations. Sydney: University of Sydney.

Obi, J. N., \& Agwu, E. (2017). Effective Decision-Making and Organizational Goal Achievement in a Depressed Economy. International Journal of Research and Development Studies, 8(1), 1-10.

Peschel, A. O., Orquin, J. L., \& Loose, S. M. (2019). Increasing consumers' attention capture and food choice through bottomup effects. Appetite, 132(1), 1-7.

Sandelowski, M. (2000). Whatever happened to qualitative description? Research in Nursing \& Health, 23(4), 334-340.

Turpin, S. M., \& Marais, M. (2004). Decisionmaking: Theory and practice. ORiON, 20(2), 143-160.

Wallach, W., Allen, C., \& Smit, I. (2008). Machine morality: bottom-up and topdown approaches for modelling human moral faculties. Ai \& Society, 22(4), 565582.

Wu, A. (2015). Organizational DecisionMaking and Information: Angel Investments by Venture Capital Partners Organizational Decision-Making and Information: Angel Investments by Venture Capital Partners, (781), 1-70. 